\title{
Fishery, diet composition and reproductive biology of the dolphinfish Coryphaena hippurus (Linnaeus, 1758) off Karnataka, south-west coast of India
}

\author{
K. M. RAJESH, PRATHIBHA ROHIT AND E. M. ABDUSSAMAD* \\ Research Centre of ICAR-Central Marine Fisheries Research Institute, Hoige Bazar, Mangalore - 575001 \\ Karnataka, India \\ *ICAR-Central Marine Fisheries Research Institute, Ernakulam North P.O., Kochi - 682 018, Kerala, India \\ e-mail: rajeshmkm3@rediffmail.com
}

\begin{abstract}
Fishery, diet composition and reproductive biology of the dolphinfish Coryphaena hippurus (Linnaeus, 1758) landed along Karnataka Coast during 2013-15 were studied. The estimated average landing of the species in India during the study period was $7975 \mathrm{t}$ of which Karnataka contributed $2.73 \%$ (218 t). The fish is mainly exploited by gillnet and also by troll lines operated from trawlers. A few stray specimens were also landed by purse seines. The fork length (FL) was in the range of 32-128 cm and fishes in the length range (FL) of 55-90 cm dominated the catch, contributing $79.8 \%$ of the total landings. The most dominant prey item, in terms of occurrence $(70.57 \%)$ and weight $(83.18 \%)$ were finfishes followed by cephalopods ( $19.62 \%$ by occurrence and $13.66 \%$ by weight) and crustaceans $(7.01 \%$ occurrence and $1.32 \%$ by weight). The index of relative importance (IRI ) values were $85.3,13.39$ and $0.68 \%$ respectively for fish, cephalopods and crustaceans respectively. Sex ratio (1:2.05) indicated dominance of females in the fishery. Presence of mature and spent specimens throughout the year suggests that the species spawns all through the year. Peak spawning period was from June to September. This coincided with gradual increase in gonadosomatic index (GSI) values ahead of May which reached a peak during August-September.
\end{abstract}

Keywords: Coryphaena hippurus, Diet composition, Dolphinfish, Karnataka, Reproductive biology

\section{Introduction}

The genus Coryphaena under the monogeneric family Coryphaenidae comprises only two species viz., Coryphaena hippurus (Linnaeus, 1758) and $C$. equiselis (Linnaeus, 1758) which are commonly called mahimahi or dolphinfishes. These are highly migratory, large oceanic species having a wide distribution in tropical and subtropical waters of the Pacific, Atlantic and Indian Oceans and known to occur within a few miles off the coast when wind blows steadily (Merten et al., 2014; Gatt et al., 2015). They generally occur along with large oceanic pelagic fishes and support important commercial fisheries in several regions (Losso and Zopata, 1999; Olson and Galven-Magana, 2002). These fishes have a tendency to aggregate near natural and artificial floating objects (Wickham et al., 1973). Fishermen in the Mediterranean Sea make use of the aggregating tendency to their advantage and attract them using fish aggregating devices (FAD's) moored offshore, which are then caught with surround nets (Castriota et al., 2007). However, the remarkable fast growth rate and high turnover of this species has probably made dolphinfishes less susceptible to the act of overfishing as compared to other long-lived slow maturing fishes (FWRI, 2008) and are included under the category 'least concern' in the IUCN Redlist (Collette et al., 2011). Dolphinfishes are apex predators and feeds on fishes, crustaceans and molluscs. It removes considerable amount of tertiary production from an ecosystem and consume approximately 5-6\% of its body weight each day (Olson and Galven-Magana, 2002; Guzman et al., 2015).

Occurrence of dolphinfishes in India is reported from all maritime states except West Bengal and the resource forms an important component of the fish landings of Gujarat (37\%), Daman and Diu (16.7\%), Kerala (14.3\%) and Tamil Nadu (11.9\%). The estimated annual average catch for the country during 2013-15 was $7975 \mathrm{t}$ with Karnataka contributing $2.73 \%$ (218 t) occupying sixth position among the maritime states. Fishery in Karnataka comprised only single species, C. hippurus and was observed throughout the fishing season with peak landing between August and October. Dolphinfishes are mainly caught as bycatch in gears targeting seerfish, tunas, barracudas and billfishes. They also formed part of the purse seine catch using light as fish attractant, which recently started operating in deeper waters off Karnataka. 
Studies on the fishery, diet composition, reproductive biology and stock status of dolphinfish are available from Mediterranean waters, Eastern Pacific Ocean, Tyrrhenian seas, Australian waters and northern coast of Rio de Janeiro, Brazil (Massuti et al., 1998; Oxenford, 1999; Olsan and Galvan Magana, 2002; Castroita et al., 2007; Newman, 2013; Pimenta et al., 2014; Gatt et al., 2015; Guzman et al., 2015). However, no comprehensive report is available on the fishery, diet composition and reproductive biology of dolphinfishes from Indian waters. Benjamin and Kurup (2012) reported on the stock status of the species along Kerala Coast based on their collections made at Cochin, Munambam and Neendakara fishing harbours. The present study for the first time investigated the fishery, diet composition and reproductive biology of the dolphinfish C. hippurus from Karnataka coast.

\section{Materials and methods}

Data on C. hippurus landed during 2013-2015 by different commercial fishing vessels were obtained from the data bank of National Marine Fisheries Data Centre (NMFDC) of ICAR-Central Marine Fisheries Research Institute (ICAR-CMFRI), Kochi. Fortnightly samples were collected for biological studies from Mangalore and Malpe landing centres of Karnataka from gillnet and hook and lines, as majority of the dolphinfish was landed on a regular basis by these gears. The fork length (FL) of 953 fishes was measured to the nearest $\mathrm{cm}$. Diet composition and reproductive biology was studied based on observations from a total of 256 fishes. Monthly collections were made thoughout the year, except during the monsoon months of June and July when there was a ban on the operation of mechanised fishing units. Stomachs from individual fishes were carefully dissected out and preserved for further detailed analysis. Based on the absence or presence of food, the stomach fullness was visually classified into six categories as: full, three-fourth full, half full, one-fourth full, trace and empty. Total weight of the stomach contents was recorded and food items were divided into broad prey classes viz., fishes, molluscs and crustaceans. The weight of each prey item was taken separately.

Point's method (Hyslop, 1980) was used to provide weightage to different food items in the stomach. The keys and identification characteristics as described in Smith and Heemstra (1986) and Fischer and Whitehead (1974) were followed to identify the prey up to genus/species level. The index of relative importance (IRI) of each food item in the diet was determined following Pinkas et al. (1971).
Based on the macroscopic appearance of the ovary and testes in the body cavity, maturity stages of females and males were classified with suitable modification as per the ICES scale described by Lovern and Wood (1937). The homogeneity of male and female distribution was determined by Chi-square test using monthly sex ratio. The gonadosomatic index (GSI) was calculated using the equation:

GSI $=[\text { Gonad weight } / \text { (body weight }- \text { gonad weight) }]^{*} 100$

\section{Results and discussion}

Fishery

Along Karnataka Coast, dolphinfishes are exploited mainly by crafts operating gillnet (43\%) and also by troll lines operated from trawlers $(37 \%)$, purse seines $(14 \%)$ and other indigenous gears $(6 \%)$ such as ringseines and shoreseines. The landings of trawls, gillnets, purseseines, ringseines and shoreseines confirms the extent of distributional availability of dolphinfish very close to the coast and in deeper areas. Similar type of wide distributional abundance from within a few miles of the coast to offshore deeper waters has been very well documented in tropical and subtropical waters (FAO, 1994; Collette, 1999). Similarly, exploitation of the dolphinfish by different gears such as purse seines (Olson and Galvin- Magana, 2002) in Pacific Ocean, longlines (Gatt et al., 2015), drifting longlines, troll lines and surrounding nets (Castriota et al., 2007) in Mediterranean waters have been reported. The estimated annual catch of dolphinfish in Karnataka during 2013-2015 ranged between $136.3 \mathrm{t}$ (2013) and 307.1 t (2014), with a mean of $209.3 \mathrm{t}$ and accounted for $2.7 \%$ of the country's dolphinfish catch (7975 t).

\section{Seasonal abundance}

Dolphinfish was landed in all months with peak during September and October (Fig. 1) and moderate landings during August and November. Minimum catch was recorded during June-July as the fishing ban is imposed on the operation of mechanised boats. Minimal catch was recorded by a few motorised units operating gillnets during June-July.

\section{Length distribution}

The fork length (FL) ranged from 32 to $128 \mathrm{~cm}$ but fishes having 55 to $90 \mathrm{~cm}$ FL dominated the catch (79.8\%) (Fig. 2). Modal lengths were at 80 and $60 \mathrm{~cm}$ and the estimated annual mean length was $74.2 \mathrm{~cm}$. Similar length ranges of $45-127.5 \mathrm{~cm}$ (Rose and Hassler, 1974), 35.8-147.9 cm (Perez et al., 1992), 40-120 cm (Oxenford, $1985)$ and 35.8-132.3 cm (Perez and Sadovy, 1991) have been reported from North Carolina, Puerto Rico, Barbados and Puerto Rico respectively. However, Benjamin and 


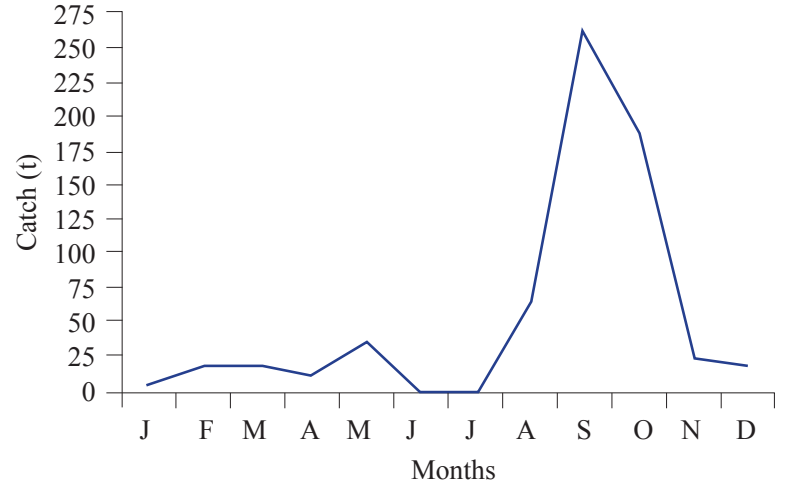

Fig. 1. Monthly trends in landings of $C$. hippurus in Karnataka during 2013-2015

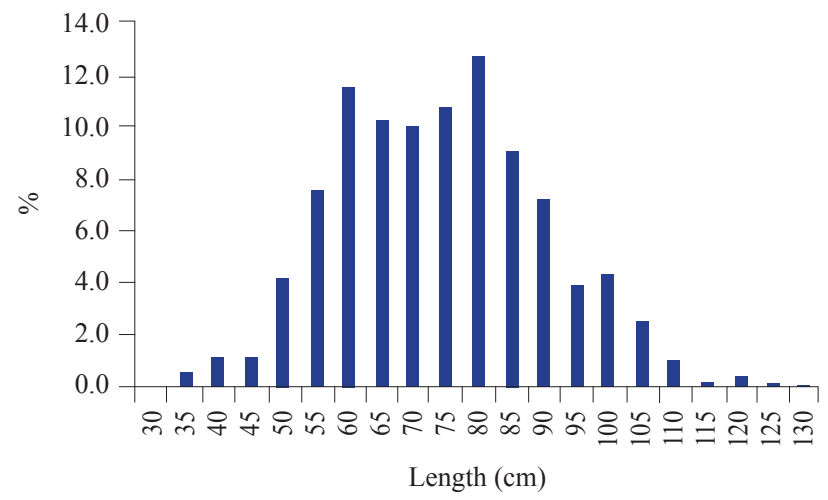

Fig. 2. Length frequency distribution of $C$. hippurus landed in Karnataka during 2013-2015

Kurup (2012) have reported a higher length range of 55-185 cm for dolphinfish in the Arabian Sea off Kerala. The size frequency distribution recorded in our study is comparable with other studies conducted in North Pacific Ocean (Ditty et al., 1994), Eastern tropical Pacific (Zuniga et al., 2008), Central Mediterranean (Gatt et al., 2015) and Pacific Panama (Guzman et al., 2015).

\section{Food and feeding}

Among the 256 guts of dolphinfish analysed, 122 (48\%) were empty, 45 (17\%) full, 41 (16\%) trace, $35(14 \%)$ were half full and $13(5 \%)$ were three-fourth full. Dolphinfishes are believed to be visual predators and primarily feed during day time (Massuti et al., 1998). The higher numbers of empty stomach recorded here could be due to the collection of samples from multiday gillnets and trawls operating during night time. Juanes and Conover (1994) too have made similar observations and opined that high percentage of empty stomachs is normal among large fishes which prey mainly on other fishes.

Prey items were mainly represented by three major taxonomic groups viz., fishes; crustaceans and cephalopods. The most dominant prey item, both by occurrence $(70.57 \%)$ and weight $(83.18 \%)$ were teleosts followed by cephalopods $(19.62 \%$ by occurrence and $13.66 \%$ by weight) and crustaceans $(7.01 \%$ by occurrence and $1.32 \%$ by weight). The $\%$ IRI values were $85.3,13.39$ and 0.68 respectively for fish, cephalopods and crustaceans (Table 1). Results indicate that $C$. hippurus like other large pelagic fishes feed opportunistically on several prey items (Oxenford, 1999). Predominance of fishes in the diet of dolphinfish has been pointed out in earlier studies carried out in Mediterranean waters (Massuti et al., 1998), Eastern Pacific Ocean (Olson and Galvan-Magana, 2002), Tyrrhenian seas (Castriota et al., 2007) and along the coast of Rio De Janerio, Brazil (Pimenta et al., 2014).

The most important teleost prey items were the pelagic and mesopelagic fish species viz., Decapterus russelli, Encrasicholina devisi, Lagocephalus inermis, Trichiurus lepturus, Sardinella longiceps, Scomberomorus commerson and Megalaspis cordyla (Table 1). This is an indication of energy transfer between the epipelagic and mesopelagic environments through the food web, which emphasised the importance of the dolphinfish predatory activity in the whole pelagic system (Castriota et al., 2007). Fishes were generally present in a highly digestible condition and unidentifiable remains accounted for the highest percentage among prey items $(\% \mathrm{~F}=17.76$, $\% \mathrm{~N}=19.47, \% \mathrm{~W}=22.41$ and $\% \mathrm{IRI}=27.54)($ Table 1$)$.

Cephalopods were the second most dominant diet found in the gut following fishes. Among cephalopods, Loligo sp. was the predominant prey $(15.42 \%$ by occurrence, $10.18 \%$ by number, $12.84 \%$ by weight and $1.14 \%$ by IRI) followed by Sepia and Octopus (Table 1). Crustaceans comprising shrimps and crabs formed only very less quantity. Prey importance varied according to the area and availability of food organisms. Fish as the main diet component and the minor role of cephalopods and crustaceans in the diet of dolphinfish has been documented (Massuti et al., 1998; Olson and Galvan-Magana, 2002; Castriota et al., 2007; Pimenta et al., 2014).

\section{Reproductive biology}

\section{Sex ratio}

Of the 256 dolphinfishes analysed, 84 were males $(32.81 \%)$ and 172 females $(67.19 \%)$. Male to female ratio was $1: 2.05$, which indicated dominance of females in the fishery. Monthwise, female dominance was evident throughout the year (Table 2).

Dominance of females was noticeable in almost all the months (Table 2). Such sexual differentiation with dominance of females may be attributed to the migration undertaken for the purpose of spawning. Similar dominance of female dolphinfish in the fishery has been 
Table 1. Index of relative importance (IRI) of food items in the diet of C. hippurus

\begin{tabular}{|c|c|c|c|c|c|}
\hline & $\%$ Frequency & $\%$ Number & $\%$ Weight & $\begin{array}{l}\text { Index of relative } \\
\text { importantance }\end{array}$ & $\%$ IRI \\
\hline Fish (Combined) & 70.57 & 80.08 & 83.18 & 2303.22 & 85.3 \\
\hline Decapterus russelli & 21.03 & 19.03 & 32.07 & 1074.39 & 39.79 \\
\hline Partially digested fishes (Unidentified) & 17.76 & 19.47 & 22.41 & 743.67 & 27.54 \\
\hline Encrasicholina devisi & 10.75 & 26.99 & 5.80 & 352.39 & 13.05 \\
\hline Lagocephalus inermis & 5.61 & 2.21 & 10.12 & 69.14 & 2.56 \\
\hline Trichiurus lepturus & 4.21 & 1.33 & 4.25 & 23.47 & 0.87 \\
\hline Sardinella longiceps & 4.21 & 2.21 & 2.31 & 19.02 & 0.70 \\
\hline Scomeromorus commerson & 1.40 & 6.64 & 0.05 & 9.38 & 0.35 \\
\hline Megalaspis cordyla & 1.40 & 0.44 & 2.64 & 4.33 & 0.16 \\
\hline Hemiramphus sp. & 1.40 & 0.88 & 1.72 & 3.65 & 0.14 \\
\hline Nemipterus japonicus & 1.40 & 0.44 & 1.03 & 2.07 & 0.08 \\
\hline Epinephelus sp. & 2.80 & 4.42 & 1.84 & 17.56 & 0.09 \\
\hline Ablennes hians & 1.40 & 0.44 & 0.78 & 1.71 & 0.06 \\
\hline Cephalopods (Combined) & 19.62 & 11.95 & 13.66 & 361.4 & 13.39 \\
\hline Loligo sp. & 15.42 & 10.18 & 12.84 & 354.88 & 13.14 \\
\hline Octopus & 2.80 & 1.33 & 0.73 & 5.77 & 0.22 \\
\hline Sepia sp. & 1.40 & 0.44 & 0.09 & 0.75 & 0.03 \\
\hline Crustaceans (Combined) & 7.01 & 3.53 & 1.32 & 18.17 & 0.68 \\
\hline Shrimps & 4.21 & 2.65 & 0.59 & 13.64 & 0.51 \\
\hline Crabs & 2.80 & 0.88 & 0.73 & 4.53 & 0.17 \\
\hline
\end{tabular}

Values are means of three years (2013-2015)

noticed and reported from other parts of the world (Table 3) and is more of a temporary behaviour and not due to sexual differentiation during conception or selective mortality of a particular sex (Oxenford, 1999). This is clearly reflected by the Chi-square test (Table 2) which also did not indicate significant difference in distribution of males and females during different months.

\section{Length at first maturity}

Out of the 256 specimens collected 250 (97.7\%) were found to be mature and had attained stage III and above. Among the 6 immature fishes, 4 males $(45-48 \mathrm{~cm}$ FL) and 2 females ( 42 and $45 \mathrm{~cm} \mathrm{FL)} \mathrm{were} \mathrm{in} \mathrm{stage} \mathrm{II} \mathrm{of}$ gonadal maturity. The smallest mature male and female

Table 2. Monthly sex ratio of $C$. hippurus landed in Karnataka during 2013-2015

\begin{tabular}{lll}
\hline Months & Sex ratio (Female/male) & Chi-square value \\
\hline January & 1.18 & 1.846 \\
February & 1.89 & 0.038 \\
March & 2.14 & 0.010 \\
April & 2.20 & 0.018 \\
May & 1.71 & 0.140 \\
August & 3.17 & 0.881 \\
September & 2.89 & 0.800 \\
October & 2.71 & 0.409 \\
November & 1.91 & 0.035 \\
December & 1.44 & 0.654
\end{tabular}

" $\mathrm{p} \leq 0.05$ observed were at 47 and $49 \mathrm{~cm}$ FL respectively. About $90 \%$ of the fishes observed in the study measured above $55 \mathrm{~cm}$ FL. This may be because of the dominant catch of the species by gillnets. However, more number of smaller fishes needs to be observed for the accurate determination of minimum size at maturity. Beardesly (1967) observed maturation of female dolphinfish at about $35 \mathrm{~cm}, 50 \%$ at $45 \mathrm{~cm}$ and $100 \%$ at $55 \mathrm{~cm} \mathrm{FL}$. The males matured at slightly larger size ( $42.7 \mathrm{~cm} \mathrm{FL)}$ as compared to females.

\section{Gonadosomatic index (GSI)}

The GSI values ranged from 0.89 to 1.74 for male and 1.61 to 6.32 for female fishes. Higher GSI values were recorded during August and September (Fig. 3) indicating high reproductive activity during these months.

Table 3. Overall sex ratios reported for dolphinfish from different parts of the world

\begin{tabular}{lll}
\hline Location & Sex ratio (M:F) & Reference \\
\hline Virgin Islands & $1: 1.9$ & Mather (1954) \\
North Carolina & $1: 1.9$ & Rose and Hasler (1974) \\
Puerto Rico & $1: 3.0$ & Erdman (1976) \\
Florida current & $1: 1.8$ & Oxenford (1985) \\
Barbados & $1: 3.0$ & Oxenford (1985) \\
Gulf of Mexico & $1: 1.2$ & Bentivoglio (1988) \\
Puerto Rico & $1: 2.3$ & Perez et al. $(1992)$ \\
Maltese waters, & $1: 1.5$ & Gatt et al. $(2015)$ \\
Central Mediterranean & &
\end{tabular}




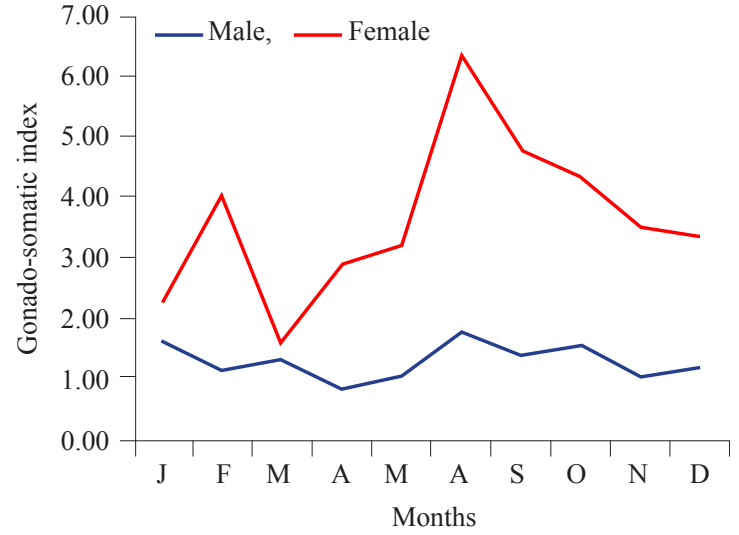

Fig. 3. Monthly mean gonadosomatic indices (GSI) for male and female C. hippurus

The presence of mature and spent specimens throughout the year suggests that dolphinfish spawns all through the year. However, the peak spawning period recorded during June to September coincides with gradual increase in GSI value ahead of May, with peak values in AugustSeptember which gradually reduced thereafter. The protracted multiple spawning behaviour of dolphinfish is very well documented (Palko et al., 1982; Oxenford, 1985; Perez and Sadovy, 1991). The occurrence of dolphinfish larvae all through the year in the Florida Current (Powles and Stender, 1976 and Schekter, 1982) and Gulf of Mexico (Ditty et al., 1994) indicates year round spawning. Continuous spawning was reported in dolphinfish broodstock caught from the Florida Current kept in captivity for several months.

C. hippurus is a pelagic predator, feeding mainly on pelagic and mesopelagic fishes. Such piscivorous diet indicates energy transfer between the epipelagic and mesopelagic systems in the marine foodweb. The presence of mature and spent specimens throughout the year suggests that dolphinfish spawns all through the year with a peak during June to September and it coincided with the higher GSI values recorded during the same period. This comprehensive account on the major biological characteristics of $C$. hippurus is the first of its kind from Indian waters, that would form basic information for future studies and also for the management, conservation and judicious exploitation of the species.

\section{Acknowledgements}

Authors would like to express their gratitude to the Director, ICAR-CMFRI, Kochi for facilitating this work as well as for the constant support and encouragement.

\section{References}

Beardsley, G. L. 1967. Age, growth and reproduction of the dolphinfish, Coryphaena hippurus in the straits of Florida. Copeia, 2: 441-451.
Benjamin, D. and Kurup, M. 2012. Stock assessment of dolphinfish Coryphaena hippurus (Linnaeus, 1758) off south-west coast of India. J. Mar. Biol. Ass. India, 54(1): 95-99.

Bentivoglio, A. A. 1988. Investigations into the growth, maturity, mortality rates and occurrence of the dolphin (Coryphaena hippurus, Linnaeus) in the Gulf of Mexico. M. Sc. thesis. University College of North Wales, Bangor, UK.

Castriota, L., Pipitone, C., Campagnuolo, S., Romanelli, M., Potoschi, A. and Andaloro, F. 2007. Diet of Coryphaena hippurus (Coryphaenidae) associated with FADs in the Ionian and Southern Tyrrhenian seas, Cybium, 31(4): 435-441.

Collette, B. B. 1999. Coryphaenidae, dolphin fishes (dolphins), FAO species identification guide for fishery purposes. In: Carpenter, K. E. and Niem, V. H. (Eds.), The living marine resources of the Western Central Pacific, vol, 4. Bony fishes part 2 (Mugilidae to Carangidae). FAO, Rome, Italy, p. 2656-2658.

Collette, B., Acero, A., Amorim, A. F., Boustany, A., Canales Ramirez, C., Cardenas, G., Carpenter, K. E., de Oliveira Leite Jr., N., Di Natale, A., Fox, W., Fredou, F.L., Graves, J., VieraHazin, F. H., Juan Jorda, M., Minte Vera, C., Miyabe, N., Montano Cruz, R., Nelson, R., Oxenford, H., Schaefer, K., Serra, R., Sun, C., TeixeiraLessa, R. P., Pires Ferreira Travassos, P. E., Uozumi, Y. and Yanez, E. 2011. Coryphaena hippurus. The IUCN Red List of Threatened Species 2011: e.T154712A4614989.http:// dx.doi.org/10.2305/IUCN.UK. 2011-2.RLTS.T154712A4 614989. en. (Accessed 23 June 2016)

Ditty, J. G., Shaw, R. F., Grimes, C. B. and Cope, J. S. 1994. Larval development, distribution and abundance of common dolphin (Coryphaena hippurus) and pompano dolphin (Coryphaena equiselis) in the Northern Gulf of Mexico. Fish. Bull., 92: 275-291.

Erdman, D. S. 1976. Spawning patterns of fishes from the north-eastern Caribbean. Commonwealth of Puerto Rico, Agricultural and Fisheries Contributions, Official Publication of the Area of Special Services, 8(2): 1-34.

FAO 1994. World review of highly migratory species and straddling stocks. Food and Agriculture Organisation. Rome, Italy. FAO Fisheries Technical Paper, No. 337: 70 pp.

Fischer, W. and Whitehead, P. J. P. 1974. FAO species identification sheets for fishery purposes. Eastern Indian Ocean (Fishing area 57) and Western Central Pacific (Fishing area 71), vol. 1-4.

FWRI 2008. Dolphin-general facts. Fish and Wildlife Research Institute, Florida, p. 55-58.

Gatt, M., Dimech, M. and Schembri, P. J. 2015. Age, growth and reproduction of Coryphaena hippurus (Linnaeus, 1758) in Maltese waters, Central Mediterranean. Medit. Mar. Sci., 16(2): 334-345.

Guzman, H. M., Ferguson, E. D. Vega, A. J. and Robles, Y. A. 2015. Assessment of the dolphinfish Coryphaena hippurus (Perciformes: Coryphaenidae) fishery in Pacific Panama. Rev. Biol. Trop., 63(3): 705-716. 
Hyslop, E. J. 1980. Stomach contents analysis - a review of methods and their applications. J. Fish Biol., 17(4): 411-429.

Juanes, F. and Conover, D. O. 1994. Rapid growth, high feeding rates and early piscivory in young of the year blue fish (Pomatomus saltatrix). Can. J. Fish. Aquat. Sci., 51(8): 1752-1761.

Lasso, J. and Zapata, L. 1999. Fisheries and biology of Coryphaena hippurus in the Pacific coast of Colombia and Panama. Sci. Mar., 63(3-4): 387-399.

Lovern, J. A. and Wood, H. 1937. Variations in the biochemical composition of herring. J. Mar. Biol. Ass. U.K., 22: 281-293.

Massuti, E., Deudero, S., Sanchez, P. and Morales-Nin, B. 1998. Diet and feeding of dolphin (Coryphaena hippurus) in Western Mediterranean waters. Bull. Mar. Sci., 63(2): 329-341.

Mather, F. J. 1954. Northerly occurrences of warm water fishes of the tropical Atlantic. Copeia, 54(4): 292-293.

Merten, W., Appeldoorn, R. and Hammond, D. 2014. Movement of dolphinfish (Coryphaena hippurus) along the US east coast as determined through mark and recapture data. Fish. Res., 151: 114-121.

Newman, S. 2013. Mahimahi (Coryphaena hippurus). In: Smallwood, C. B., Hesp, S. A. and Beckley, L. E. (Eds.), Biology, stock status and management summaries for selected fish species in south-western Australia. Fisheries Research Report No. 242. Department of Fisheries, Western Australia. 180 pp.

Olson, R. J. and Galvan-Magana, F. 2002. Food habits and consumption rates of common dolphinfish (Coryphaena hippurus) in the Eastern Pacific Ocean. Fish. Bull., 100(2): 279-298.

Oxenford, H. A. 1985. The biology of the dolphin fish Coryphaena hippurus and its implications for the Barbadian fishery Doctoral thesis, University of the West Indies, Cave Hill, Barbados.

Oxenford, H. A. 1999. Biology of the dolphinfish (Coryphaena hippurus) in the Western Central Atlantic: a review. Sci. Mar., 63(3-4): 277-301.

Palko, B. J., Beardsley, G. L. and Richards, W. J. 1982. Synopsis of the biological data on dolphinfishes, Coryphaena hippurus Linnaeus and Coryphaena equiselis Linnaeus.
FAO Fish. Synop. (130), NOAA Technical Report, NMFS Circ., 28 pp.

Perez, R. N. and Sadovy, Y. 1991. Preliminary data on landing records and reproductive biology of Coryphaena hippurus in Puerto Rico. Gulf and Caribbean Fisheries Institute, 44: 636-650

Perez, R. N., Roman, A. M. and Rivera, G. A. 1992. Investigation of the reproductive dynamics and preliminary evaluation of landings data of the dolphinfish Coryphaena hippurus, L. Final Report for Dingell-Johnson Project F26-1. Puerto Rico Department of Natural Resources Fishery Research Laboratory, Mayaguez, PR, 95 pp.

Pimenta, E. G., Vieira, Y. C., Marques, L. A., Gomes, T. X. and de Amorim, A. F. 2014. Analysis of stomach contents of dolphinfish, Coryphaena hippurus, Linnaeus, 1758 (Actinopterygii, Coryphaenidae), off the northern coast of Rio de Janeiro State, Brazil. Collect. Vol. Sci. Pap. ICCAT, 70: 2954-2960.

Pinkas, L., Oliphant, M. S. and Iverson, I. L. K. 1971. Food habits of albacore, bluefin tuna and bonito in Californian waters. Calif. Dep. Fish. Game Fish. Bull., 152: 1-105.

Powles, H. and Stender, B. W. 1976. Observations on composition, seasonality and distribution of ichthyoplankton from MARMAP cruises in the South Atlantic Bight in 1973. South Carolina Marine Research Centre Technical Report Series, 11, $47 \mathrm{pp}$.

Rose, C. D. and Hasler, W. W. 1974. Food habits and sex ratios of dolphin, Coryphaena hippurus, captured in the Western Atlantic Ocean off Hatteras, North Carolina. Trans. Am. Fish. Soc., 103: 94-100.

Schekter, R. C. 1982. Mariculture of dolphin (Coryphaena hippurus): Is it feasible? Proc. Gulf Caribb .Fish. Instit., 35: 27-32.

Smith, M. M. and Heemstra, P. C. 1986. Smiths' sea fishes Southern Book Publications, Johanesburg, 907 pp.

Wickham, D. A., Watson, Jr. J. W. and Ogren, L. H. 1973. The efficacy of midwater artificial structures for attracting pelagic sport fish. Trans. Am. Fish. Soc., 102(3): 563-572.

Zuniga, M., Ortega-Garcia, S. and Klett-Traulsen, A. 2008. Interannual and seasonal variation of dolphinfish (Coryphaena hippurus) catch rates in the southern Gulf of California, Mexico. Fish. Res., 94(1): 13-17. 